\title{
Assay of Serum/Plasma $\beta$ - $N$-Acetylhexosaminidase Isoenzymes by Heat Inactivation Using a Continuous Spectrophotometric Method Adapted to a Centrifugal Analyzer
}

\author{
19
}

\author{
Luis F. Pérez and J. Carlos Tutor
}

Laboratorio Central, Hospital General de Galicia-Clínico Universitario, Santiago de Compostela, Spain

\begin{abstract}
Summary: Activity of serum/plasma $\beta-N$-acetylhexosaminidase (EC 3.2.1.52) was determined by means of a continuous spectrophotometric method using 3,3'-dichlorophenylsulphonphthaleinyl- $N$-acetyl- $\beta$ - $D$-glucosaminide as substrate, with very satisfactory results. Incubation of an undiluted aliquot $(1 \mathrm{ml})$ of samples at $52^{\circ} \mathrm{C}$ for 8 hours with an adjusted pH 5.5-6.0 provoked only the inactivation of isoenzyme A, thus allowing the evaluation of $\beta-N$ acetylhexosaminidase isoenzyme composition. In 25 serum samples from control subjects and pregnant women, a good correlation between the percentage of isoenzyme B obtained by this procedure and the fluorimetric assay of $O$ 'Brien et al. (New Engl J Med 1970; 273:15-20) was found $\left(\mathrm{r}=0.983, \mathrm{~S}_{\mathrm{yx}}=1.51\right)$, with no statistically significant difference between the means (43.2 vs $42.8 \%$ ). In 84 healthy adult subjects, an average value of $30.3 \%$ for the proportion of isoenzyme B was obtained, with an interval of $25.4-35.0 \%$, in agreement with results reported by other authors.
\end{abstract}

\section{Introduction}

The lysosomal enzyme $\beta$ - $N$-acetylhexosaminidase (EC 3.2.1.52) ${ }^{1}$ ) consists of two major isoenzymes, denoted $\mathrm{A}$ and $\mathrm{B}$. $\beta$ - $N$-Acetylhexosaminidase $\mathrm{A}$ is a heterodimer composed of $\alpha$ and $\beta$ subunits, whereas $\beta-N$-acetylhexosaminidase $B$ is a homodimer solely comprised of $\beta$ subunits $(1,2)$. The so called intermediate forms $(\beta-N$ acetylhexosaminidase I), including $P$-form which increase in serum during pregnancy, are post-translational modifications.

Until a few years ago, the almost exclusive clinical application of $\beta-N$-acetylhexosaminidase assay was the biochemical diagnosis of gangliosidoses $\mathrm{G}_{\mathrm{M} 2}$ (Sandhoff's and Tay-Sachs diseases) and the detection of carriers. However, more recent studies have revealed a developing interest in other physiopathological situations $(3-11)$. For the determination of the $\beta-N$-acetylhexosaminidase isoenzymes, various electrophoretic, chromatographic and immunochemical techniques have been proposed, although the traditional heat inactivation assays are still used more often due to their simplicity (1). These methods are based on the varying stability of isoenzymes A and B with increases in temperature. Under conditions where the $\mathrm{pH}$ is 4.4 , isoenzyme $\mathrm{B}$ is relatively thermostable for a temperature of $50-55^{\circ} \mathrm{C}$, whereas isoenzyme $\mathrm{A}$ is rapidly inactivated. In order to

1) Enzyme

$\beta-N$-acetylhexosaminidase:

$\beta$ - $N$-acetyl- $D$-hexosaminide $N$-acetylhexosamino hydrolase EC 3.2.1.52 perform heat treatment of the samples a large dilution is done with a citrate buffer, which requires a high analytical sensitivity of the assay for the measurement of enzyme activity. This is carried out using substrates derived from 4-methylumbelliferone that become fluorescent chromophore when hydrolyzed by the enzyme. A large number of synthetic substrates have been manufactured which allow spectrophotometric determination of $\beta-N$-acetylhexosaminidase activity $(7,12)$; however, their lower analytical sensitivity makes it difficult to adapt them to this particular type of differential heat inactivation assay of $\beta-N$-acetylhexosaminidase isoenzymes.

In the present study a heat inactivation procedure at $52^{\circ} \mathrm{C}$ was developed that permitted the determination of $\beta$ - $N$-acetylhexosaminidase isoenzymes in serum/plasma using a continuous spectrophotometric method adapted to a centrifugal analyzer.

\section{Materials and Methods}

Catalytic activities of $\beta-N$-acetylhexosaminidase were measured using 3,3'-dichlorophenylsulphonphthaleinyl- $N$-acetyl- $\beta$ - $D$-glucosaminide as substrate (13) by means of the commercially available reagent NAG Rate Test ${ }^{\circledR}$ from Shionogi and Col., Ltd. (Chuo-Ku, Osaka, Japan). Activity determinations were performed in a Cobas Bio centrifugal analyzer (Roche Diagnostics, Basel, Switzerland) programmed as follows: Units U/1; Calculation factor 587 (see results section); Standard 1-3 Conc. 0; Limit 0; Temperature [Deg. C] 37.0; Type of Analysis 2; Wavelength [nm] 575. Sample Volume $[\mu \mathrm{l}]$ 10; Diluent Volume $[\mu \mathrm{l}]$ 50; Reagent Volume $[\mu \mathrm{l}]$ 150; Incubation Time [sec.] 0: Start Reagent Volume $[\mu \mathrm{l}]$ 0; Time of First Reading [sec.] 300; Time Interval [sec.] 30; Numbers of Readings 10; Blanking Mode 1; Prontout Mode 2. For the preparation 
of the reagent solution, $8.2 \mathrm{ml}$ of distilled water was added to each bottle containing lyophilized synthetic substrate and buffer. Under these conditions, the final concentration of the substrate in the reaction mixture was the same as that specified in the instructions for the manual procedure. The calculation factor was established regarding the enzyme activity of Precimat $\beta-\mathrm{NAG}^{\circledR}$ and Precinorm $\beta-N_{A G}{ }^{\circledR}$ standards (Boehringer Mannheim GmbH, Mannheim, Germany) whose assigned values are calculated on the basis of the molar absorptivity of the released chlorophenolred under standardized conditions (14).

It must be pointed out that the enzyme activity found therefore for the Stand $\mathrm{NAG}^{\circledR}$ control from Shionogi and Co., Ltd., was on average $68 \%(n=18)$ of the assigned value by the manufacturer. This fact could be due to the assigned enzyme activity for this control material occurring so that the continuous method using the 3,3 '-dichlorophenylsulphonphthaleinyl- $N$-acetyl- $\beta-D$-glucosaminide substrate gave equivalent activity to that of the discontinuous method using the substrate $m$-cresolsulphonphthaleinyl- $N$-acetyl- $\beta$ $D$-glucosaminide (15). However, the results obtained by various authors have demonstrated that the use of the substrate $m$-cresolsulphonphthaleinyl- $N$-acetyl- $\beta$ - $D$-glucosaminide gives significantly higher enzyme activity than when 3,3'-dichlorophenylsulphonphthaleinyl- $N$-acetyl- $\beta-D$-glucosaminide is used $(16-18)$. Consequently, if the Stand NAG ${ }^{\circledR}$ control is used then the programmed calculation factor in the analyzer should be 863 .

A pH-meter for biological fluids Radiometer model ABL-300 (Radiometer, Copenhagen, Denmark) was used for determining the $\mathrm{pH}$ of serum samples.

Statistical analysis of the data was carried out using the SPSS package. To check for normality, skewness and kurtosis coefficients or the Shapiro-Wilk test were used, depending on the size of the sample. The significance of difference between mean values was evaluated by the Wilcoxon sign range test for matching data and by the Mann-Whitney $U$ test for unpaired data. Normally distributed data were analyzed statistically by means of Pearson's correlation coefficient, otherwise Spearman's coefficient was used. Linear regression analysis was performed using the Passing-Bablok method. A p-value less than 0.05 was considered to be significant.

\section{Results}

When the 3,3'-dichlorophenylsulphonphthaleinyl- $N$-acetyl- $\beta$ - $D$-glucosaminide method was used to determine the activity of $\beta-N$-acetylhexosaminidase in urine, excluding the slight enzyme-inhibiting effect of urea, it did not appear that other endogenous metabolites, such as urobilinogen, bilirubin, haemoglobin or glucose could seriously interfere $(17,19)$. However, it was necessary to investigate the possible effect of elevated concentrations of albumin and globulins so that this substrate could be used for determining enzyme activity in serum or plasma. To do this, different quantities of bovine albumin (Ektachem Solution Bovine Serum Albumin ${ }^{\circledR}$, Johnson and Johnson Clinical Diagnostics Inc., Rochester, USA) were added to different Precimat $\beta-\mathrm{NAG}^{\circledR}$ control vials belonging to the same lot. The results obtained are presented in figure 1 , showing that bovine albumin produces an inhibitory effect on $\beta$ - $N$-acetylhexosaminidase activity. Human albumin produced an analogous inhibition, since the addition of fresh serum samples from different patients, whose $\beta-N$-acetylhexosaminidase activity had been previously determined, provided equivalent results to those that would be expected

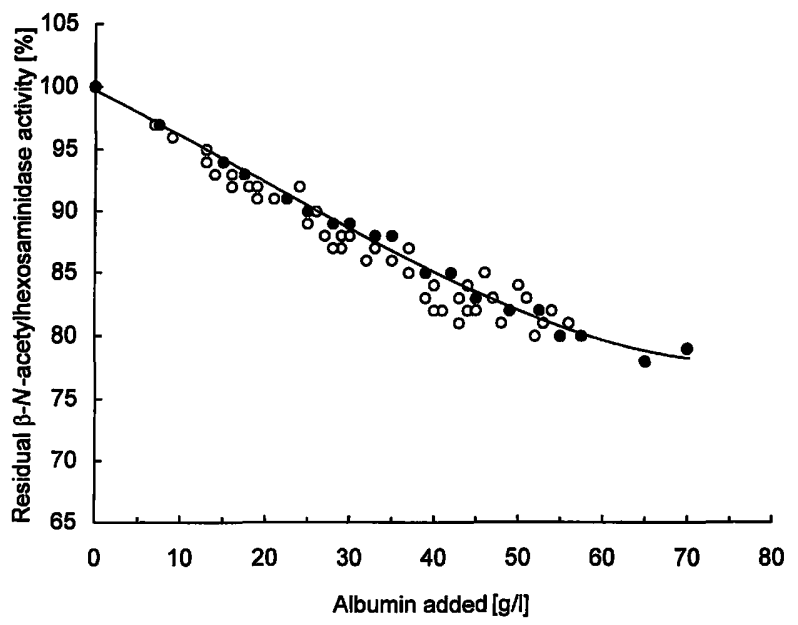

Fig. 1 Inhibiting effect of bovine (•) and human (o) serum albumin on $\beta$ - $N$-acetylhexosaminidase activity from bovine kidney (Precimat $\beta$-NAG ${ }^{\circledR}$ ) using 3,3'-dichlorophenylsulphonphthaleinyl$N$-acetyl- $\beta$ - $D$-glucosaminide as substrate.

in function of its albumin concentration (fig. 1). Therefore, it did not appear that globulins had any effect on $\beta$ - $N$-acetylhexosaminidase activity when 3,3'-dichlorophenylsulphonphthaleinyl- $N$-acetyl- $\beta-D$-glucosaminide was used as substrate. The inhibitory effect produced by albumin was of a non-competitive type, as implied by the Lineweaver-Burk plot obtained. The inhibition of albumin on the $\beta-N$-acetylhexosaminidase A (ref. A8527) and $\beta$ - $N$-acetylhexosaminidase $\mathrm{P}$ (ref. A9175) purified human placental isoenzymes from Sigma Chemical Co. (St. Louis, USA), and the $\beta$ - $N$-acetylhexosaminidase from bovine kidney (Precimat $\beta-\mathrm{NAG}^{\circledR}$ ) presents an analogous magnitude.

Consequently, in order to determine $\beta$ - $N$-acetylhexosaminidase in serum/plasma and in pleural or peritoneal fluids, the enzyme activities obtained should be recalculated by means of the correction factors relevant to the albumin concentration shown in table 1 . In any case, a

Tab. 1 Correction factors for $\beta$ - $N$-acetylhexosaminidase activity in function of the sample albumin concentrations.

\begin{tabular}{lll}
\hline $\begin{array}{l}\text { Albumin } \\
(\mathrm{g} / \mathrm{l})\end{array}$ & $\begin{array}{l}\text { Residual activity } \\
(\%)\end{array}$ & $\begin{array}{l}\text { Correction } \\
\text { factor }\end{array}$ \\
\hline 0 & 100 & 1.000 \\
4 & 98 & 1.020 \\
8 & 97 & 1.031 \\
12 & 95 & 1.053 \\
16 & 94 & 1.064 \\
20 & 92 & 1.087 \\
24 & 91 & 1.099 \\
28 & 89 & 1.124 \\
32 & 88 & 1.136 \\
36 & 86 & 1.163 \\
40 & 85 & 1.176 \\
44 & 84 & 1.190 \\
48 & 83 & 1.205 \\
52 & 81 & 1.235 \\
56 & 81 & 1.235 \\
60 & 80 & 1.250 \\
\hline
\end{tabular}


calculation factor of $700(587 \times 1.192)$, corresponding to an albumin concentration of $45 \mathrm{~g} / \mathrm{l}$, may be used in the programmation of the analyzer for routine determination of serum $\beta$ - $N$-acetylhexosaminidase activity. The inaccuracy resulting from this approximation would be a maximum of $2.5 \%$ for serum albumin concentrations included in the reference interval. In 35 serum samples from patients with different liver diseases and with an average albumin concentration of $36 \mathrm{~g} / 1$ (interval $=18-$ $51 \mathrm{~g} / \mathrm{l})$, the activities thus obtained gave an excellent correlation against the individually corrected values for the albumin concentration $\left(r=0.997, S_{y . x}=0.45\right)$, with no statistically significant difference between the means (11.4 U/1 vs $11.0 \mathrm{U} / \mathrm{l})$.

The precision obtained in the determination of serum $\beta$ - $N$-acetylhexosaminidase must be considered as very good, as shown in table 2 , where the enzyme activity remained unaltered for at least 60 days in samples frozen at $-20^{\circ} \mathrm{C}$. In all cases, the coefficient of variation was less than the medically accepted value according to the criteria of the College of American Pathologists (20).

An excellent correlation was achieved between the enzyme activities in serum obtained by means of the continuous method using 3,3'-dichlorophenylsulphonphthaleinyl- $N$-acetyl- $\beta-D$-glucosaminide (CPR-NAG) and the discontinuous method using 2-methoxy-4-(2'-nitrovinyl)-phenyl- $N$-acetyl- $\beta$ - $D$-glucosaminide (MNP-NAG) as substrate, also adapted to the Cobas Bio according to the guidelines provided by the manufacturer of the reagent (Praill, Price and Richardson Diagnostics Ltd., London, UK): CPR-NAG $=0.72 \times$ MNP-NAG +0.67 $\left(\mathrm{n}=93, \mathrm{r}=0.977, \mathrm{~S}_{\mathrm{y} . \mathrm{x}}=0.525\right)$. The correlation between serum $\beta$ - $N$-acetylhexosaminidase activities obtained with 3,3'-dichlorophenylsulphonphthaleinyl- $N$ acetyl- $\beta$ - $D$-glucosaminide (CPR-NAG) and a fluorimetric method using 4-methylumbelliferyl- $N$-acetyl $-\beta-D$ glucosaminide (4MU-NAG) as substrate was also excellent: CPR-NAG $=0.29 \times 4 \mathrm{MU}-\mathrm{NAG}-0.09(\mathrm{n}=25$, $\mathrm{r}=0.995, \mathrm{~S}_{\mathrm{y} \cdot \mathrm{x}}=0.682$ ).

Tab. 2 Study of precision in determining serum $\beta-N$-acetylhexosaminidase activity in the Cobas Bio analyzer.

\begin{tabular}{|c|c|c|c|c|c|c|c|c|}
\hline & \multicolumn{4}{|c|}{ Within-run precision } & \multicolumn{4}{|c|}{ Between-run precision } \\
\hline & $\mathbf{n}$ & $\begin{array}{l}\text { Mean } \\
(\mathrm{U} / \mathrm{l})\end{array}$ & $\begin{array}{l}\mathrm{SD} \\
(\mathrm{U} / \mathrm{l})\end{array}$ & $\begin{array}{l}\text { CV } \\
(\%)\end{array}$ & $\mathrm{n}$ & $\begin{array}{l}\text { Mean } \\
(\mathrm{U} / \mathrm{l})\end{array}$ & $\begin{array}{l}\mathrm{SD} \\
(\mathrm{U} / \mathrm{l})\end{array}$ & $\begin{array}{l}\text { CV } \\
(\%)\end{array}$ \\
\hline Serum 1 & 21 & 7.1 & 0.07 & 0.99 & 21 & 7.4 & 0.13 & 1.78 \\
\hline Serum 2 & 21 & 14.9 & 0.13 & 0.87 & 21 & 14.6 & 0.24 & 1.64 \\
\hline Serum 3 & 21 & 36.2 & 0.26 & 0.72 & 21 & 38.1 & 0.35 & 0.92 \\
\hline Precinorn* & 21 & 5.2 & 0.06 & 1.15 & 15 & 5.3 & 0.11 & 2.08 \\
\hline Precimat* & 21 & 52.1 & 0.33 & 0.63 & 18 & 53.2 & 0.44 & 0.83 \\
\hline
\end{tabular}

* Lyophilized control materials reconstituted with $1 \mathrm{ml}$ of bovine serum albumin solution $70 \mathrm{~g} / 1$.

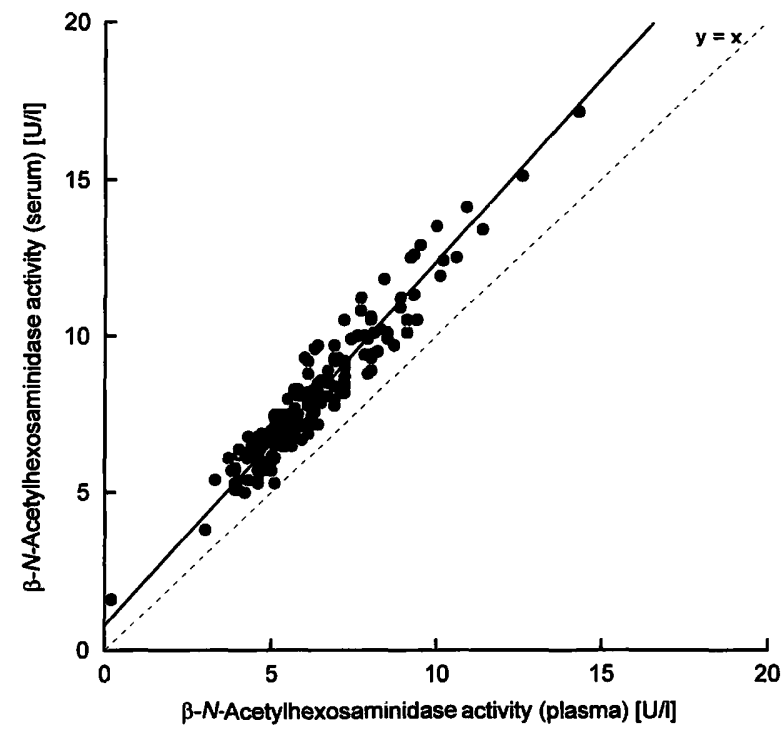

Fig. 2 Correlation and regression between serum and plasma $\beta$ $N$-acetylhexosaminidase activities using 3,3'-dichlorophenylsulphonphthaleinyl- $N$-acetyl- $\beta$ - $D$-glucosaminide as substrate $\left(\mathrm{n}=196, \mathrm{y}=1.16 \mathrm{x}+0.78, \mathrm{r}=0.955, \mathrm{~S}_{\mathrm{y} . \mathrm{x}}=0.456\right)$.

The possible effect of different anticoagulants on $\beta-N$ acetylhexosaminidase activity was investigated by adding 4 pools of sera to Vacutainer ${ }^{\circledR}$ tubes (Becton-Dickinson Vacutainer Systems, Rutherford, USA) to half the volume of blood drawn into the tubes. No significant change in enzyme activity was observed due to the lithium heparinate, $\mathrm{K}_{3} \mathrm{EDTA}$, sodium citrate or citratedextrose (data not shown).

The parallel analysis of $\beta-N$-acetylhexosaminidase activities in serum and plasma (blood collected with $\mathrm{K}_{3}$ EDTA as anticoagulant) gave the results shown in figure 2, where values in serum were significantly higher than in plasma $(p<0.001)$. This fact was not due to a simple dilution effect produced by the anticoagulant, as this was taken into account when calculating the activities in plasma. The difference between the means was superior to the medically acceptable error according to the criteria of the College of American Pathologists (20). A highly significant correlation between the difference of serum/plasma activity and the platelet count in blood was found, as shown in figure 3. This difference in activity also shows a statistically significant correlation with the packed platelet volume and the leukocyte count in blood (tab. 3). Nevertheless, since the platelet and leukocyte counts showed a significant correlation between themselves $(r=0.500, p<0.001)$, the partial correlation between the difference of serum/ plasma activity and the leukocyte count, keeping the platelet count constant, did not reach statistical significance $(r=0.180$, NS).

In 187 sera from healthy adult subjects of both sexes, we found a mean activity of $7.3 \mathrm{U} / 1$ (SEM $=0.09$; interval $=5.1-10.2 \mathrm{U} / \mathrm{l}$ ) and in 114 plasma samples a mean 


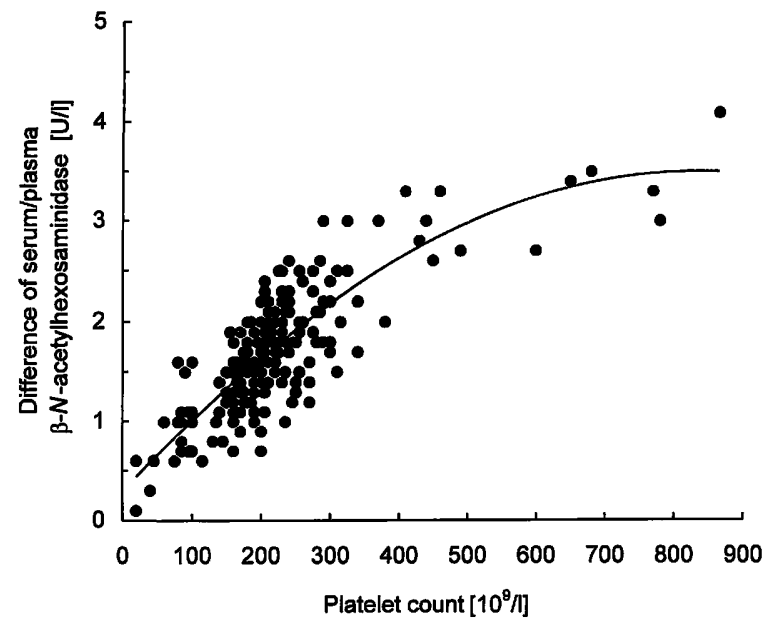

Fig. 3 Correlation between the difference of serum/plasma $\beta-N$ acetylhexosaminidase activity and the platelet count $(n=196$, $\mathrm{r}=0.756, \mathrm{p}<0.001)$.

activity of $5.4 \mathrm{U} / 1$ (SEM $=0.10$; interval $=3.7-8.0$ $\mathrm{U} / 1$ ), using 3,3'-dichlorophenylsulphonphthaleinyl- $N$ acetyl- $\beta$ - $D$-glucosaminide as substrate. In agreement with other authors $(21,22)$ no significant difference was found for the enzyme activity with regard to sex.

Since the heat inactivation of the enzymes is strongly influenced by the protein concentration of the medium (23), for the selective heat inactivation of isoenzyme $A$ in samples of undiluted native serum, a careful optimization of the experimental conditions had to be carried out. A study published in 1993 by Isaksson et al. (24) was used as a starting point. In this work it was pointed out that after the incubation of 5 serum samples at $37^{\circ} \mathrm{C}$ for 15 hours, more than $80 \%$ of isoenzyme $\mathrm{B}$ remained and less than $10 \%$ of isoenzyme A, whose catalytic activity and antigenic properties were destroyed together.

The incubation of 11 native serum samples at $37^{\circ} \mathrm{C}$, in aliquots of $1 \mathrm{ml}$ in closed tubes, led to an inactivation of $\beta$ - $N$-acetylhexosaminidase which was stabilized after 12 hours, as shown in figure 4 . Once separated from the clot, the serum suffered an increase in $\mathrm{pH}$ due to a loss of $\mathrm{CO}_{2}$ depending on the temperature and the empty space remaining in the tube above the samples (25). The rapid inactivation at room temperature of the serum acid phosphatase was attributed to this increase in $\mathrm{pH}$ (25). $\beta$ - $N$-Acetylhexosaminidase in serum would appear to be more stable, since its remains fairly active under these conditions for a period of at least 24 hours $(26,27)$, a fact which we have confirmed. However, at $37^{\circ} \mathrm{C}$, in samples that reach $\mathrm{pH} \approx 8.5$, alkalinization could play an important role in the inactivation of $\beta$ - $N$-acetylhexosaminidase. As shown in figure 4, acidification with citric acid of the serum samples to $\mathrm{pH} \approx 6.0$ prevents the inactivation of $\beta-N$-acetylhexosaminidase during incubation at $37^{\circ} \mathrm{C}$.

Subsequently, a systematic study of the $\mathrm{pH}$ effect of serum samples on the heat inactivation of $\beta$ - $N$-acetylhexosaminidase was carried out, although in order to optimize the operative methodology, incubation was performed at $52{ }^{\circ} \mathrm{C}$. This temperature was established as a compromise value in view of the temperature interval $\left(50-55^{\circ} \mathrm{C}\right)$ recommended by various authors for the heat inactivation of isoenzyme $A$ in diluted serum samples with a buffer $(1,26,31,36)$. According to $O^{\prime}$ Brien et al. (26), temperatures lower than $48^{\circ} \mathrm{C}$ lead to the incomplete inactivation of isoenzyme $\mathrm{A}$, whereas temperatures higher than $52{ }^{\circ} \mathrm{C}$ produce a significant inactivation of isoenzyme $\mathrm{B}$. Residual activities in aliquots of a sera pool adjusted to different $\mathrm{pH}$ values with citric

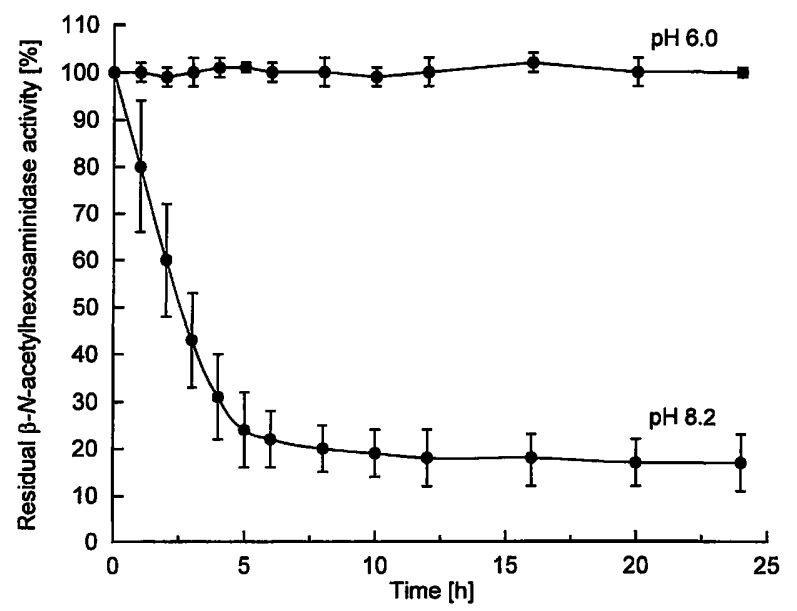

Fig. 4 Stability of $\beta$ - $N$-acetylhexosaminidase at $37^{\circ} \mathrm{C}$ in 11 native $(\mathrm{pH} \approx 8.2)$ and acidified $(\mathrm{pH} \approx 6.0)$ sera. The results are expressed as mean $\pm \mathrm{SD}$.

Tab. 3 Correlation between the difference of serum/plasma $\beta$ - $N$-acetylhexosaminidase activity and the platelet and leukocyte counts $(n=196)$.

\begin{tabular}{|c|c|c|c|c|c|}
\hline & \multirow{2}{*}{$\begin{array}{l}\text { Platelet count } \\
\left(10^{9} / 1\right)\end{array}$} & \multirow{2}{*}{$\begin{array}{l}\text { Packed platelet } \\
\text { volume } \\
(\%)\end{array}$} & \multicolumn{3}{|c|}{ Leukocyte count } \\
\hline & & & $\begin{array}{l}\text { Total } \\
\left(10^{9} / 1\right)\end{array}$ & $\begin{array}{l}\text { Polymorpho- } \\
\text { nuclear } \\
\left(10^{9} / 1\right)\end{array}$ & $\begin{array}{l}\text { Mono- } \\
\text { nuclear } \\
\left(10^{9} / 1\right)\end{array}$ \\
\hline Range: & $20.0-865.0$ & $0.01-0.87$ & $1.2-31.0$ & $0.7-26.2$ & $0.4-4.6$ \\
\hline Serum/plasma difference (U/l) & 0.756 & 0.676 & 0.384 & 0.350 & 0.305 \\
\hline
\end{tabular}

In all cases, a significant correlation for $\mathrm{p}<0.001$ was found. 
acid for different periods of incubation at $52{ }^{\circ} \mathrm{C}$ are shown in figure 5 . For the most acidic $\mathrm{pH}$ values $(\mathrm{pH}$ 4.8 ) and the most alkaline ( $\mathrm{pH} 8.2)$ assayed, a complete inactivation of $\beta$ - $N$-acetylhexosaminidase was obtained with an incubation of 2-4 hours. Different residual activities were found for the intermediate $\mathrm{pH}$ values studied, which were stabilized in every case at 8 hours of heat treatment (fig. 5). Consequently, the $\mathrm{pH}$ effect of the samples was systematically investigated in a sera pool taken from healthy control subjects and from another pool of pregnant women adjusted to different $\mathrm{pH}$ values and subjected to an 8 hours incubation period at $52{ }^{\circ} \mathrm{C}$. The results obtained are shown in figure 6 . It can be seen that the maximum residual activity for both sera pools was obtained for the interval of $\mathrm{pH}$ 5.5-6.0. Above and below these limit values a rapid fall in enzyme activity can be observed, mainly for more acidic $\mathrm{pH}$ values, in which a plainly visible white protein precipitate was noted.

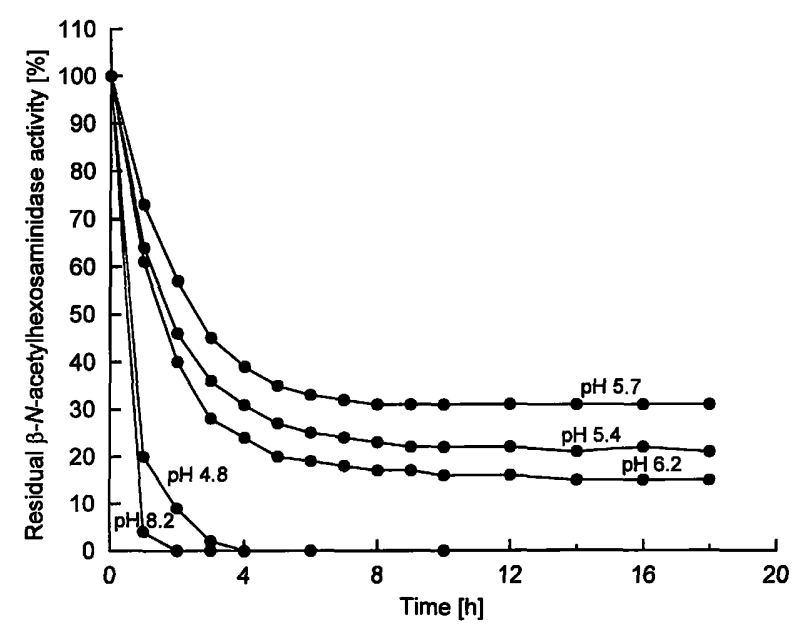

Fig. 5 Time course for heat inactivation of $\beta-N$-acetylhexosaminidase at $52{ }^{\circ} \mathrm{C}$ in a pool of sera adjusted to different $\mathrm{pH}$ values.

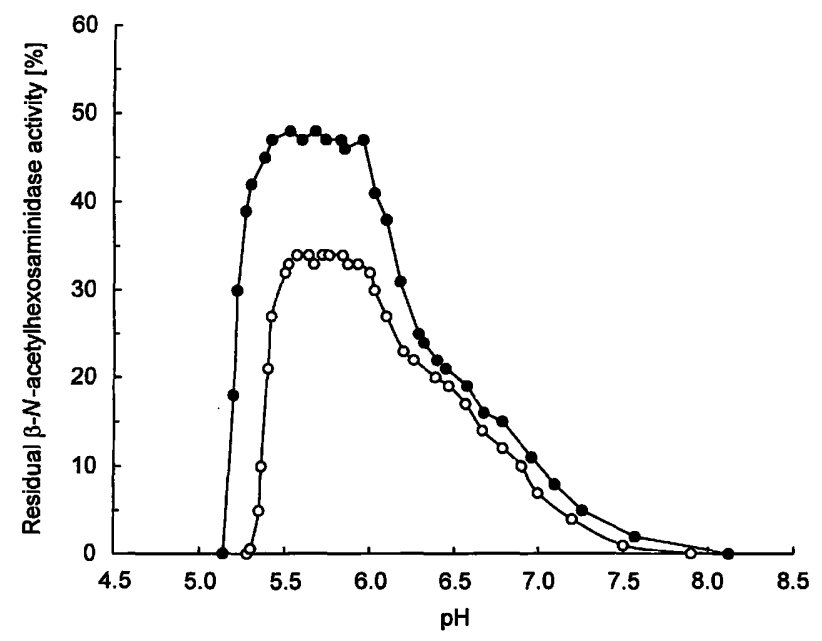

Fig. 6 Inactivation of serum $\beta$ - $N$-acetylhexosaminidase by heat treatment at $52{ }^{\circ} \mathrm{C}$ for 8 hours in a control subjects sera pool (o) and another one from pregnant women $(\bullet)$ adjusted to different $\mathrm{pH}$ values.

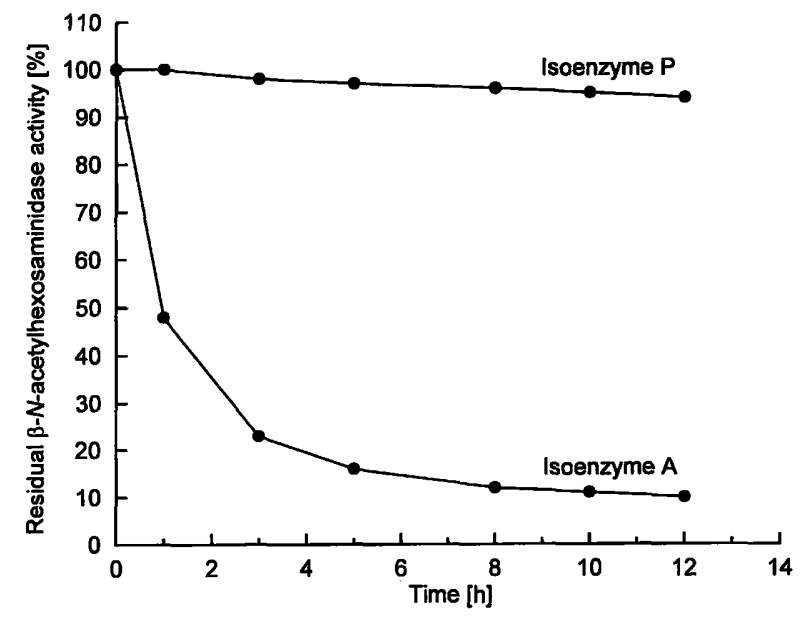

Fig. 7 Time course for heat treatment at $52^{\circ} \mathrm{C}$ and $\mathrm{pH} \approx 5.8$ on activity of $\beta$ - $N$-acetylhexosaminidase $A$ and $P$ human placental isoenzymes.

Incubation at $52^{\circ} \mathrm{C}$ and $\mathrm{pH} \approx 5.8$ of $\beta$ - $N$-acetylhexosaminidase $\mathrm{A}$ and $\mathrm{P}$ purified human placental isoenzymes, supplemented with bovine serum albumin $50 \mathrm{~g} / \mathrm{l}$, lead to the results shown in figure 7. The residual activity after 8 hours of incubation was always more than $95 \%$ for $\beta-N$-acetylhexosaminidase $\mathrm{P}$, whilst for isoenzyme A it was about $10 \%$. An electrophoretic study in cellulose acetate showed that this commercial purified isoenzyme A presents an additional fraction with mobility similar to isoenzyme B and which represents about $10 \%$ of the total activity. This would explain the residual activity found in the heat inactivation assay. On the contrary, the purified $\beta-N$-acetylhexosaminidase $\mathrm{P}$ showed a single homogeneous electrophoretic band with similar migration to that of isoenzyme $B$.

The only difference between serum $\beta$ - $N$-acetylhexosaminidase $\mathrm{P}$ and isoenzyme $\mathrm{B}$ seems to be that $\mathrm{P}$-form contains more sialic acid (28). Threehundred $\mu$ l of a neuraminidase (EC 3.2.1.18) solution from Vibrio cholerae $1 \mathrm{kU} / 1$ (Boehringer Mannheim $\mathrm{GmbH}$ ), free of $\beta$ $\mathrm{N}$-acetylhexosaminidase activity, were added to $1 \mathrm{ml}$ of different $\mathrm{pH}$ adjusted sera $(\mathrm{pH} \approx 5.8)$ from healthy control subjects and pregnant women $(n=8)$ and, after being incubated at room temperature for 7-24 hours, the respective assays of heat inactivation at $52{ }^{\circ} \mathrm{C}$ was carried out. The desialylation of $\beta-N$-acetylhexosaminidase by the neuraminidase did not significantly modify the residual activity values obtained (data not shown), which suggests that $P$-form and isoenzyme $B$ show analogous thermostability. The heat inactivation assay of isoenzyme A was carried out in 10 aliquots of $1 \mathrm{ml}$ from a sera pool adjusted to $\mathrm{pH} \approx 5.8$, giving a mean residual activity of $53.7 \%$, with a SD $=0.79$ and therefore a $\mathrm{CV}=1.47 \%$.

In 25 serum samples taken from control subjects and pregnant women a mean value of $43.2 \%$ for the proportion of isoenzyme B was obtained, by means of the heat 
inactivation procedure described, and of $42.8 \%$ by the fluorimetric assay of $O$ 'Brien et al. (26), showing a good correlation between the values: 4MU-NAG $=0.96 \times$ CPR-NAG $+1.30\left(\mathrm{r}=0.983, \mathrm{~S}_{\mathrm{y} \cdot \mathrm{x}}=1.51, \mathrm{p}<0.001\right)$.

Therefore, the heat treatment of native serum samples adjusted to $\mathrm{pH} 5.5-6.0$ and incubated at $52{ }^{\circ} \mathrm{C}$ for 8 hours permits the differential inactivation of isoenzymes $\mathrm{A}$ and $\mathrm{B}$. The addition of $11 \mu \mathrm{l}$ of acetic acid at $20 \%$ to $1 \mathrm{ml}$ of serum, or of a tablet containing $4 \mathrm{mg}$ of citric acid (Prostatic Acid Stabilizer Tablets ${ }^{\circledR}$, Sigma Chemical Co.) to $1.5 \mathrm{ml}$ of serum, provided the samples with a $\mathrm{pH} \approx 5.8$, which is very suitable for the inactivation of isoenzyme $\mathrm{A}$ under the conditions described. In the case of women in their 5th-9th month of pregnancy, a suitable $\mathrm{pH}$ was obtained by adding $10 \mu \mathrm{l}$ of acetic acid at $20 \%$ to $1 \mathrm{ml}$ of serum. This is possibly due to the haemodilution which occurs over this period. The addition of acetic or citric acid to different serum samples as described $(n=20)$ led to about $3 \%$ loss of enzyme activity.

In a control group of 84 healthy adult subjects, isoenzyme $A$ and $B$ activity in serum was determined using the heat inactivation procedure described, leading to an average value for the proportion of isoenzyme B of $30.3 \%(\mathrm{SEM}=0.28 \%)$ with a reference interval of $25.4-35.0 \%$.

\section{Discussion}

The above results demonstrate that $\beta-N$-acetylhexosaminidase activity in serum or plasma can be determined rapidly and precisely using 3,3'-dichlorophenylsulphonphthaleinyl- $N$-acetyl- $\beta$ - $D$-glucosaminide as substrate. The albumin seemed to be able to bind with this substrate, subsequently forming the ternary complex enzyme-inhibitor-substrate and hindering the formation of the chromophore, which would be in agreement with the type of non-competitive inhibition found. When using 2 -methoxy-4-(2'-nitrovinyl)-phenyl- $N$-acetyl- $\beta-D$-glucosaminide as substrate, no significant inhibition of the $\beta-N$-acetylhexosaminidase was noted, even using albumin concentrations of $70 \mathrm{~g} / 1$. The different molecular structures of both substrates could explain why the 3,3'dichlorophenylsulphonphthaleinyl- $N$-acetyl- $\beta-D$-glucosaminide, whose molecule includes three benzene rings, is bound to the albumin, while the 2-methoxy-4-(2'-nitrovinyl)-phenyl- $N$-acetyl- $\beta$ - $D$-glucosaminide, whose less bulky molecule with only one benzene ring, would not create a bond with this protein. In any case, this inhibition does not seem to be a serious drawback for the use of 3,3'-dichlorophenylsulphonphthaleinyl- $N$-acetyl- $\beta-D$ glucosaminide to determine the $\beta-N$-acetylhexosaminidase in biological fluids with high concentrations of albumin such as serum or plasma.
As far as the difference in activity of the $\beta-N$-acetylhexosaminidase in serum and plasma is concerned, and even the possible effects of anticoagulants, the bibliographic data are not conclusive. O'Brien et al. (27) and Natowicz et al. (29) do not find significant differences between enzyme activity in serum and plasma. On the other hand, Suzuki et al. (30) and $O^{\prime} B r i e n$ (31) point out that $\beta$ $N$-acetylhexosaminidase would be inhibited by heparin, which could explain the lower activity obtained in plasma collected with this anticoagulant. However, according to Lombardo et al. (32), heparin, citrate, oxalate or EDTA would not affect per se $\beta$ - $N$-acetylhexosaminidase activity, as our results have also shown. Likewise, these authors find significantly higher $\beta$ - $N$-acetylhexosaminidase activity in serum than in plasma, and suggest that the release of enzyme from the platelets could occur during coagulation. Recently, Emiliani et al. (33) have demonstrated that stimulation with thrombin provokes a release by platelets of $\beta-N$-acetylhexosaminidase and other glycohydrolases.

We also found greater enzyme activity in serum than in plasma, there being a highly significant correlation between the difference in serum/plasma activity and the platelet count (fig. 3), which clearly supports the hypothesis suggested by Lombardo et al. (32). On the other hand, the partial correlation study which was carried out seems to indicate that no significant release of leukocyte $\beta-N$-acetylhexosaminidase to serum takes place during coagulation.

The procedure developed for the heat inactivation of isoenzyme $\mathrm{A}$ at $52^{\circ} \mathrm{C}$ for 8 hours in specimens of serum or plasma adjusted to $\mathrm{pH} 5.5-6.0$, allows for the use of spectrophotometric methods in the evaluation of the $\beta$ $N$-acetylhexosaminidase isoenzyme composition. The addition of acetic or citric acid to the serum samples, as indicated in the results, produces a slight inactivation of $\beta$ - $N$-acetylhexosaminidase (approx. 3\%) which must be taken into account. Acetate shows a clear inhibitory effect on $\beta$ - $N$-acetylhexosaminidase $(1,34)$, however, the low concentrations reached in the reaction mixture under experimental conditions used here must be considered.

The study of heat inactivation using the procedure described, carried out with the purified human placental $\beta$ $N$-acetylhexosaminidase $\mathrm{P}$, showed a residual activity of more than $95 \%$ in every case. Regarding the residual activity found in purified human placental isoenzyme $\mathrm{A}$ (approx. 10\%), it may be explained by contamination of this preparation by isoenzyme B discovered electrophoretically. The conversion of isoenzyme $A$ to isoenzyme $B$, by reordering the subunits in the purified tissue forms, is well documented in literature $(1,35)$.

The substrate 3-methylumbelliferyl- $N$-acetyl- $\beta$ - $D$-glucosaminide is commonly used in laboratories interested 
in the study of $\beta-N$-acetylhexosaminidase isoenzymes, as it offers suitable sensitivity due to the chromophore released by the enzymatic action being fluorogenic. However, fluorimetric methods require dedicated equipment, and the low solubility of 4-methylumbelliferyl- $\mathrm{N}$ acetyl- $\beta-D$-glucosaminide and its instability in solution, as well as problems in interlaboratory standardization (7, 12) should also be considered as possible drawbacks. It is in this aspect that spectrophotometric methods could offer certain advantages, and could be used in the evaluation of the $\beta$ - $N$-acetylhexosaminidase isoenzyme composition in serum or plasma using the procedure de-

\section{References}

1. Gravel RA, Clarke JTR, Kaback MM, Mahuran D, Sandhoff $K$, Suzuki K. The $G_{M 2}$ Gangliosidoses. In: Scriver $C R$, Beaudet A, Sly WS, editors. The metabolic and molecular bases of inherited disease. 6th ed. New York: McGraw-Hill Inc., 1995:2839-79.

2. Mahuran DJ. $\beta$-Hexosaminidase: biosynthesis and processing of the normal enzyme, and identifications of mutations causing Jewis Tay-Sachs disease. Clin Biochem 1995; 28:101-6.

3. Goi G, Burlina AB, Bairati C, Bordugo A, Zanardo V, Zacchello F, et al. Enzymes of lysosomal origin in plasma of twin neonates. Clin Chim Acta 1993; 214:61-71.

4. Lügerin N, Stoll R, Siekmann A, Faulhaber J, Heese C, Dietrich $\mathrm{O}$, et al. Elevated levels of activities of $\beta$-hexosaminidase and $\alpha$-mannosidase in human immunodeficiency virus-infected patients. J Infect Dis 1995; 171:683-6.

5. Hultberg B, Isaksson A, Berglund M, Moberg AL. Serum $\beta$ hexosaminidase isoenzymes: a sensitive marker for alcohol abuse. Alcohol Clin Exp Res 1991; 15:549-52.

6. Hultberg B, Isaksson A, Berglund M, Alling C. Increases and time-course variations in beta-hexosaminidase isoenzyme B and carbohydrate-deficient transferrin in serum from alcoholics are similar. Alcohol Clin Exp Res 1995; 19:452-6.

7. Price RG. Measurement of N-acetyl- $\beta$-D-glucosaminidase and its isoenzymes in urine. Methods and clinical applications. Eur J Clin Chem Clin Biochem 1992; 30:693-705.

8. Hashimoto R, Adachi H, Nishida H, Tsuruta M, Nomura G. Serum $\mathrm{N}$-acetyl- $\beta$-D-glucosaminidase activity in predicting the development of hypertension. Hypertension 1995; 25:1311-4.

9. Hultberg B, Isaksson A, Nilsson JA, Lindgarde F. Serum betahexosaminidase isoenzymes are related to risk factors for atherosclerosis in a large population of postmenopausal women. Clin Chim Acta 1994; 227:59-68.

10. Garvey MJ, Noel M. Association of levels of N-acetyl-betaglucosaminidase with specific psychiatric symptoms in bipolar patients. Psychiatric Res 1993; 47:129-39.

11. Garvey MJ, Noyes R. Association of levels of N-acetyl-betaglucosaminidase with severity of psychiatric symptoms in panic disorders. Psychiatric Res 1996; 60:185-90.

12. Price RG. New colorimetric substrates for the assay of hydrolytic enzymes: N-acetyl- $\beta$-D-glucosaminidase (NAG). Milano (Italy): Chimica Oggi 1991; 6:15-9.

13. Noto A, Nakajima K, Sasakura K, Sugasawa T. Method for determination of NAGase and reagent therefore. Eur Patent Appl 0294804, 1988.

14. Jung K, Priem F, Klein G. A new kinetic method for the measurement of $\beta-\mathrm{N}$-acetylglucosaminidase activity in urine. Wien Klin Wochenschr 1991; 103 Suppl 189:37-42.

15. Shionogi and Co., Ltd. NAG Rate Test. [technical information]. Osaka (Japan).

16. Jung K, Priem F, Klotzek S, Becker S, Henke W. Methods compared for determining activity of $\mathrm{N}$-acetyl- $\beta$ - $\mathrm{D}$-glucosaminidase in urine without pretreatment of sample: different sensitivity and species effect. Enzyme 1991; 45:215-21. scribed here for the heat inactivation of isoenzyme A. The values obtained for the proportion of isoenzymes $A$ and $B$ in 84 healthy adult subjects of both sexes are analogous to those given by other authors using different analytical methods $(5,24,35-37)$.

\section{Acknowledgements}

We wish to thank Dr. Amparo Chabás (Departamento de Neuroquímica, Instituto de Bioquímica Clínica, Barcelona, Spain) for her collaboration in the analysis of samples using the fluorimetric assays.

17. Klein G. Results of the multicenter evaluation of a new method for the determination of $\beta-\mathrm{N}$-acetylglucosaminidase in urine. Wien Klin Wochenschr 1991; 103 Suppl 189:30-7.

18. Klein G. Discussion on $\beta$-N-acetylhexosaminidase in urine. Wien Klin Wochenschr 1991; 103 Suppl 189:52-4.

19. Boehringer Mannheim GmbH. Test-Combination $\beta-N A G$ urinary. [technical information]. Mannheim (Germany).

20. Knoll E, Hafner F, Dettmer K, Wisser H. The determination of calcium, urea and uric acid using the Kodak Ektachem multilayer film technology: an evaluation. J Clin Chem Clin Biochem 1982; 20:491-7.

21. Annunziata $P, D i$ Matteo G. Study of influence of sex and age on human serum lysosomal enzymes by using 4-methylumbelliferyl substrates. Clin Chim Acta 1978; 90:101-6.

22. Lombardo A, Goi GC, Marchesini S, Caimi L, Moro M, Tettamanti G. Influence of age and sex on five human plasma lysosomal enzymes assayed by automated procedures. Clin Chim Acta $1981 ; 113: 141-52$.

23. Wagenknecht C, Papies B. Kinetic methods for determination of isoenzyme activities. In: Scheuch D, Haschen RJ, Hofmann $\mathrm{E}$, editors. Multiple forms of enzymes. Basel: S. Karger, 1982:31-42.

24. Isaksson A, Hultberg B, Masson P, Landels E, Fensom A. Enzyme immunoassay of $\beta$-hexosaminidase $A$ and $B$ in serum: carrier detection of $\mathrm{G}_{\mathrm{M} 2}$-gangliosidoses, and equivalence of enzyme activity and enzyme protein reactivity. Clin Chem 1993; 39:1412-5.

25. Demetriou JA, Drewes PA, Gin JB. Enzimas. In: Henry RJ, Cannon DC, Winkelman JW, editors. Clinical chemistry. Principles and technics. 2nd ed. Hagerstrown: Harper and Row Publisher, 1974:815-1001.

26. O'Brien JS, Okada S, Chen A, Fillerup DL. Tay-Sachs desease. Detection of heterozygotes and homozygotes by serum hexosaminidase assay. New Engl J Med 1970; 273:15-20.

27. Den Tandt WR. On the stability of human lysosomal enzymes at room temperature in normal and acidified plasma and serum. Clin Chim Acta 1996; 244:229-35.

28. Isaksson A, Hultberg B. Serum $\beta$-hexosaminidase isoenzymes are precursor forms. Scand J Clin Lab Invest 1995; 55:43340.

29. Natowicz MR, Prence EM, Cajolet A. Marked variation in blood beta-hexosaminidase in Gaucher disease. Clin Chim Acta 1991; 203:17-22.

30. Suzuki Y, Berman PH, Suzuki K. Detection of Tay-Sachs disease heterozygotes by assay of hexosaminidase $\mathrm{A}$ in serum and leucocytes. J Pediatr 1971; 78:643-7.

31. O'Brien JF. Lysosomal storage diseases. In: Burtis CA, Ashwood ER, editors. Tietz textbook of clinical chemistry. Philadelphia: WB Saunders Company, 1994:2149-60.

32. Lombardo A, Caimi L, Marchesini S, Goi GC, Tettamanti G. Enzymes of lysosomal origin in human plasma and serum: assay conditions and parameters influencing the assay. Clin Chim Acta 1980; 108:337-46. 
33. Emiliani C, Martino S, Orlacchio A, Vezza R, Nenci GG, Gresele P. Platelet glycohydrolase activities: characterisation and release. Cell Biochem Funct 1995; 13:31-9.

34. Robinson D, Stirling JL. N-acetyl- $\beta$-glucosaminidases in human spleen. Biochem J 1968; 107:321 -7.

35. Pampols T, Codina J, Girós M, Sabater J, González-Sastre F. Tissue differences in the human N-acetyl- $\beta$-D-glucosaminidase isoenzymatic forms. Cell Molec Biol 1980; 26:187-95.

36. Coma P, Gómez-Chacón L, García-Serrano B, Fernández E, Ortiz-Apodaca MA. $\alpha$-Glucosidase and N-acetyl- $\beta$-D-glucosaminidase isoenzymes in serum. Clin Chem 1992; $38: 223-6$.
37. Saifer A, Perle G. Automated determination of serum hexosaminidase $\mathrm{A}$ by $\mathrm{pH}$ inactivation for detection of Tay-Sachs disease heterozygotes. Clin Chem 1979; 20:538-43.

\section{Received December 19, 1996/April 7, 1997}

Corresponding author: Dr. J. Carlos Tutor, Laboratorio Central, Hospital General de Galicia-Clínico Universitario, E-15705

Santiago de Compostela, Spain

Fax: +34-81-570102 